\title{
THE EFFECT OF BIG BOOKS AS TEACHING MEDIA ON THE SECOND GRADE STUDENTS' READING COMPREHENSION IN SOUTH BALI
}

\author{
Jayendra, I M. S \\ English Language Education, UniversitasPendidikanGanesha \\ md.suasta.jayendra@undiksha.ac.id \\ Nitiasih, P. K \\ English Language Education, UniversitasPendidikanGanesha \\ kertinitiasih@undiksha.ac.id \\ Mahayanti, N. W. S. \\ English Language Education, UniversitasPendidikanGanesha \\ surya.mahayanti@undiksha.ac.id
}

\begin{abstract}
The aim of this study was to investigate whether or not there was any significant effect on the second grade students' reading comprehension taught by using Big Books as teaching media. The design of this study used post test only control group of quasi experimental research. Therefore the population of this study was second grade students in south Bali. The data were analyzed by using descriptive and inferential statistical analysis. The result of the data analysis showed that students in experimental group performed better than the students in control group. It was proven by the resultthat showed the mean score of the experimental group was 81.59 while the mean score of the control group was 73.64. The result of the t-test also showed the value of t-observed $\left(\mathrm{t}_{\mathrm{obs}}\right)$ was 3.009 and the value of $t$-critical value $\left(t_{c v}\right)$ was 2.018. It shows the value of $t_{\text {obs }}$ is higher than the value of $t_{c v}$. Therefore, it could be concluded that there was significant effect of Big Books as teaching media on the second grade students' reading comprehension in south Bali.
\end{abstract}

Keywords: Big Book, media, reading comprehension, young learner

\section{INTRODUCTION}

Reading plays an important role in language learning because through reading, the students can obtain new information and experience.According toSeken \& Artini (2013)reading is a process of comprehending texts to get information in order to make the reader easy to find the world around them. In line with that, reading defined as meaningful interpretation of printed and written verbal symbols(Sinambela, Manik, \& Pangaribuan, 2015). For the beginner students, reading is learning to recognize the printed symbols that represent language in order to respond question aboutcontent of the text.Reading is an important skill that must be mastered by the students because through reading, students are expected to be able to understand more certain knowledge and information.

Among the four skills in language teaching, reading skill is often given less attention by the teachers whereas reading is natural process to get knowledge and experience. Thus, from the explanation above, reading is important for the students because they can get a lot of benefitsthrough reading.

However, reading also becomes one of complex skills because in reading, the students need to comprehend the information in the text. Comprehending the information is not an easy task for students because comprehension involves understanding the vocabulary, seeing the relationship among words and concepts, organizing idea, recognizing authors' purpose, making judgment and evaluating(Sinambela et al., 2015). According to Khruawan \& Dennis (2017), reading comprehension refers to the ability which 
the students are able to read the text accurately and effectively to get the maximum knowledge and information. It can be defined that the success of reading comprehension depends on the student's knowledge, language skills, and experience. When the students are good in reading comprehension, they will be able to get the meaning hidden in the text. Considering reading comprehension as an aspect that is very important in learning English, it should be better for the students to practice their reading comprehension starting from early age or well known as young learners.

Teaching English for young learners is different from teaching English for adultsespecially in teaching reading. It is because young learners need something which is attractive, colorful, and easy to be understood in learning process. According to(Sukmahidayanti, 2015), young learners are students in the range age of $6-12$ years. Unlike adults, young learners have their own characteristics which need to be understood by those who wish to be successful in teaching English for young learners. According toHarmer (2007), young learners are easy to get bored and they have limited attention span. In line with that, according to Huyen and Nga (2003), young learners get bored when they continuously study a traditional way for a long time through memorizing the material. It can be defined that the teacher should have well preparation before teaching young learners in order to make them enthusiast in learning process and make the learning process fun and enjoyable.

There are several things that can make teaching and learning process runeffectively, such as media, assessment, teaching strategy, material, teaching approach, and reference. As one important aspect in process of learning English, media need to be prepared carefully in order to have effective learning for young learners(Juhana, 2014). Media can also make the students developing their characters by involving them in reading comprehension process. One media that can be used by teacher in teaching reading is Big Book.

Hall \& O'connor (2006)stated that BigBook is a larger format book with big illustrations and big textthat ideal for teaching beginning reading in a new language to young learners. It is supported byRahim \& Harun (2010), BigBook is effective in making young learners involved in learning process, learning new vocabulary, and increasing their comprehension of the text. There are some advantages of using BigBook such as BigBook can attract young learners' attention and curiosity, BigBook creates relaxed atmosphere in learning process and can make young learners more understand about the content of the story or even stimulate students' imagination, and BigBook also can improve students' attention and participation in reading class activity(Fahmi, Suhartono, \& Arifin, 2014). According to Panduan Gerakan Literasi Sekolah di Sekolah Dasar, Direktur Jenderal Pendidikan Dasar dan Menengah Kementrian Pendidikan dan Kebudayaan(2016), BigBook is one of media that can be used to help students' literacy in Indonesia. Thus, from explanation above, Big Book is a good media that can help the teacher for teaching reading comprehension for young learners.

A study on the use of BigBook has been conducted by Mahayanti \& Asrina (2017) in the sixth grade students of SD Laboratorium UndikshaSingaraja. This study focused on the effect of BigBook as media on students' reading comprehension. The result of this study showed that students in experimental group performed better in reading comprehension than the students in control group.

Another research has been done by Ananta (2017) in SD Laboratorium UndikshaSingaraja. This study was Research and Development and it focused in developing BigBook for literacy program for second grade students in SD LaboratoriumUndikshaSingaraja. The result of this study showed that four Big Books developed were categorized as excellent media. However, these Big Books have not been implemented in order to know its effectiveness on students' reading comprehension. Thereforeit would be continued in this study.

In this present study, Big Books applied for different grade of students in another setting, in order to know whether this media was effective in different situation. This study was an experimental study in which the purpose of this study was investigating whether Big Books as teaching media have significant effect or not on students' reading comprehension between students taught by using Big Books as teaching media and students taught by conventional media. This study conducted in second grade of elementary school students in south Bali. 


\section{METHOD}

This study was in the form of Quasi experimental of Post-test Only Control Group Design which purposed to find out whether there was or not any significant effect of the used of Big Books on students' reading comprehension. The populations of this study were second grade students insouth Bali. By using lottery the researcher determined which class belongs to experimental group and which class became the control group. II A was assigned as the experimental group and II B was assigned as the control group.

Before distributing the lottery, the researcher done normality and homogeneity test. The result of the normality showed that the two classes had normal distribution and the result homogeneity test showed that those two classes were homogeneous.

There were two variables were used in this study namely independent and dependent variable. The independent variable of this study is Big Books as teaching media. Meanwhile, the dependent variable in this study is students' reading comprehension.

In this present study, there were two instruments that were used to collect the data namely lesson plan and reading comprehension test (posttest). Lesson plan was used as a guidancefor the teacher in teaching the class. Lesson plan was designed based on the syllabus, topic of Big Book, and students characteristics. Reading comprehension test (post-test) is a test given at the end of the study to measure students ${ }^{\text {ee }}$ reading comprehension after the treatment. The reading comprehension test was in form of multiple-choice type test with 20 items and matching type with 23 items. Before the instruments were tried out, the reading comprehension test was consulted with two judges to gain the content validity judgment.

The reading comprehension test was tried out to 28 students at second grade students of SD Negeri 3 Banjar Jawa.From the empirical validity, it was found that three items were not valid and those invalid items were dropped. Those items were number 11, 16, 23. Meanwhile, 20 items was valid, those items were $1,2,3,4,5,6,7,8,9,10,12,13,14,15,17,18,19,20,21$, and 22 . Those items would be used as reading comprehension test.Since, the data gained was in form of scores, so it refers to quantitative type of data. The data was described by using two types of statistical analysis, namely, descriptive statistical analysis and inferential statistical analysis. In descriptive statistical analysis, the researcher found the mean, median, mode, variance, range, and the standard deviation of the post-test. Meanwhile, in inferential statistical normality testing and hypothesis testing was done by using t-test in SPSS 24.0 Program.

\section{FINDINGS AND DISCUSSION}

The data of this study were analyzed by using two forms of statistical analysis, namely, descriptive satatistical analysis and inferential statistical analysis. In descriptive statistical analysis was done in order to find out the mean, median, mode, range and standard deviation score of each group.The result of descriptive statistics analysis can be seen in Table 1.

Table 1 Result of descriptive statistical analysis

\begin{tabular}{cccc}
\hline No & Descriptive Statistics & \multicolumn{2}{c}{ Group } \\
& Analysis & Experimental & Control \\
\hline 1 & Mean & 81.59 & 73.64 \\
2 & Median & 80.00 & 72.50 \\
3 & Mode & $80 \& 85$ & $70 \& 75$ \\
4 & Standard Deviation & 8.221 & 9.282 \\
5 & Variance & 67.587 & 86.147 \\
6 & Range & 35 & 35 \\
7 & Minimum & 65 & 60 \\
8 & Maximum & 100 & 95 \\
\hline
\end{tabular}


The mean score of experimental group was 81.59 and the mean score of control group was 73.64. It showed the mean score of students in experimental group was higher than the control group. Therefore, the interval of the mean between experimental group and control group was 7.95. After arranging the scores of the students in both classes, it was found that Median of the experimental group was 80.00 and median of the control group was 72.50. It showed that middle score of the experimental group was higher than the control group. Mode of the experimental group was 80 and 85, while mode of the control group was 70 and 75. Because there two modes in a group therefore it could be categorized as bimodal. Based on the bimodal, it showed that the most frequently score appeared in the experimental group was higher than in the control group. Range indicates the distance between the highest and lowest score in a group, therefore the range of both groups was 35. Standard deviation of the experimental group was 8,221. While, the standard deviation of the control group was 9,282. Variance of the experimental group was 67,587 , while the variance of the control group was 86,147 . It showed that the score of students in control group were more spread out than those students in experimental group.

Furthermore, after having the result of normality and homogeneity which showed that the data were normal and homogeneous, the researcher conducted the hypothesis analysis. The hypothesis was examined by using independent t-test. The results of the data were calculated by using SPSS 24.0 at $5 \%$ level of significance. There were two qualifications for determining whether the hypothesis was rejected or not. If $\mathrm{t}_{\mathrm{cv}}$ was lower than $\mathrm{t}_{\mathrm{obs}}$, null hypothesis would be rejected and alternative hypothesis would be accepted. The result of testing was displayed in the following table.

Table 2: Result of Hypothesis Testing

\begin{tabular}{|c|c|c|c|c|c|c|c|c|}
\hline $\mathrm{F}$ & Sig. & $\mathrm{t}$ & Df & $\begin{array}{l}\text { Sig. (2- } \\
\text { tailed) }\end{array}$ & $\begin{array}{r}\text { Mean } \\
\text { Difference }\end{array}$ & $\begin{array}{l}\text { Std. Error } \\
\text { Difference }\end{array}$ & Lower & Upper \\
\hline ,380 & ,541 & 3,009 & 42 & ,004 & 7,955 & 2,643 & 2,620 & 13,289 \\
\hline
\end{tabular}

Based on the Table 2, it could be seen that the value of Sig. (2-tailed) was 0.004. It indicates that the observed level of significant (sig. (2-tailed)) was less than the standard alpha level $(\alpha=0.05)$. After the result was determined, the hypothesis testing was analyzed in terms of $t_{\mathrm{obs}}\left(t\right.$ observed) and $t_{\mathrm{cv}}(\mathrm{t}$ critical value). In analyzing the $t$-test, the value of $t$-observed $\left(t_{o b s}\right)$ was compared with the $t$-critical value $\left(t_{c v}\right)$. Comparing the $t_{\mathrm{obs}}$ and $\mathrm{t}_{\mathrm{cv}}$ was purposed to measure whether the mean score of the two groups were significantly different or not.

Based on the result of the equal variances assumed, it was found that the $t_{\text {obs }}$ was 3.009. The $t$-critical value was observed by using table of critical value of the t-distribution. Based on the Table, the t-critical value for $\mathrm{df}$ (degree of freedom) 42 was 2.018. Therefore, the comparison between $\mathrm{t}_{\mathrm{obs}}$ and $\mathrm{t}_{\mathrm{cv}}$ was 3.009 $>2.018$. Since the value of $t_{\text {obs }}$ was higher than the $t_{\mathrm{cv}}$, then the null hypothesis was rejected (H0) "There is no significant effect of Big Books as teaching media on students' reading comprehension at second grade of elementary school in south Bali" and alternative hypothesis $(\mathrm{H} \alpha)$ "There is significant effect of Big Books as teaching media on students' reading comprehension at second grade of elementary school in south Bali" was accepted.

\section{Discussion}

This research was conducted to investigate whether there was any the significant effect of Big Books as teaching media on students' reading comprehension at second grade of elementary school in south Bali.

Since the design of the research is Quasi Experiment of Post-test Only Control Group, the researcher used students' score of semester academic test (summative test) from the teacher to test the normality and the homogeneity. The normality and homogeneity test were conducted to check if both classes were in normal distribution and homogenou. After knowing the classes were in normal distribution and homogenous, the lottery was conducted to decide which classes as the sample as well as decided the experimental and control group. 
Before giving the treatment, the researcher previously should prepare the instruments. The instruments that were necessary to be prepared in this study were the teaching scenario and the post-test. Since the sample of this study still categorized as young learners, in preparing the instrument the researcher used matching test in form of colored picture and simple sentence. Matching test was provided because the researcher considered the characteristics of young learners that easy to get bored, have limited attention span and need something which is colorful and easy to get bored. It is supported by Slattery \& Willis (2001) that young learners love something which is colorful. Harmer ( 2007), young learners are easy to get bored and they have limited attention span. By using matching test, hopefully the students can be more focus in answering the post test. However, in gaining the data the researcher only used objective test result.

The instruments were consulted to the researcher's supervisors. The supervisors were asked as the judges to test the content validity of the instrument. Calculation through Gregory Formula showed that the content validity was 0.79 . Based on the level of content validity, the test could be classified in high level. After the content of the post-test was valid, the try-out for the posttest was conducted in order to check the validity and the reliability. The try-out test was conducted in IIC class of SD Negeri 3 Banjar Jawa. Based on the result of empirical validity, there were 20 valid items of the try-out test, namely: item number $1,2,3,4,5,6,7,8,9,10,12$, $13,14,15,17,18,19,20,21$, and 22. Those items would be used as reading comprehension test

After doing the test, the data or students' achievement was analyzed by using descriptive and inferential statistics analysis. The result of data analysis showed that the score of experimental group which was treated by using Big Books is better than the score of the control group which was treated by using conventional media. It was proved by the mean score of the post-test between experimental and control group in which the mean score of experimental group was higher than control group. The mean score of students who were taught by using Big Books as teaching media was 81.59 while the mean score of students who were taught by using conventional media was 73.64. It can be inferred that the experimental achieve higher score than the control group which means that the experimental group could achieve better achievement rather than the control group.

Moreover, the data were analyzed inferentially to find out the significant different between students in experimental group and control group. The result of inferential statistic showed that the value of Sig. (2-tailed) was 0.004 and it was less than the standard alpha level $(\alpha=0.05)$. Tobserved (3.009) was higher than the t-critical value (2.018). Referring to the result of inferential statistical analysis, it proved that there was significant effect of Big Books as teaching media on students' reading comprehension at second grade of elementary school in south Bali. Moreover, it showed that Big Books were able to help the students comprehending the English material which made them able to improve their reading comprehension.

In this study, treatment was conducted for experimental group. This group was given the treatment eight times in which the researcher used four Big Books in this research. Themed of the first Big Book was about animal entitled Little Dog "Doggy". The themed of the second Big Book was about day entitled Days of The Week, then for the third Big Book was about greeting entitled Hello Good Morning, and the last themed of the Big Book was about clothe entitled Get Dressed. There were some activities which were done by the researcher in applying Big Book as media, as stated by Fisher (1991) in applying the Big Book. There are pre-reading activity before reading big book, reading the complete story, re-reading activity, after reading activity, and close activity. During the treatments that had been conducted, the media was applied systematically based on the procedures.

In the beginning of the treatment process, students who were taught by using Big Big Books as teaching media were not asked to make a circle in front of the researcher. It is because the 
situation of the classroom that is small that made the students were not able to have space for making circle. Therefore while showing the Big Book, the researcher asked all of the students to see the Big Book in order to check whether all of the students could see the Big Book clearly from certain distance. After all of the students could see the Big Book clearly. Then, the researcher started the pre-reading activity before reading Big Book. In this pre-reading activity, the researcher introduced the parts of Big Book such as the front cover, pages, the upper part, and the bottom part of the Big Book, the back cover and how to open the book in the right way. The researcher told the title of the book, the writer of the Big Book, and the illustrator of the Big Book loudly in order to activate the students' prior knowledge related to the story. Then, the researcher asked the students about the possible story of the Big Book based on the title and the illustration from the front cover of the book. In this activity, the students seemed really enthusiastic and happy to see the Big Book and it showed if Big Book could attract students' attention. This is in line with the statement by Fahmi et al. (2014) who state that Big Book can increase students' enthusiasm and curiosity to the material.

Second activity was reading the complete story. In this activity, the researcher read the story from the first page until the last page of the Big Book continuously with interesting expressions and intonation. It was done in order to make the students focus on the story and encourage them to read independently. It also made the students enthusiastic in listening the story. The researcher also checked students' understanding by stopping in certain page and asked the students to guess what would happen in the next page. Moreover, the researcher gave additional information about the story and the illustration of the Big Book in order to help the students in comprehending the story of the Big Book.

The third activity was re-reading activity. In this activity, the researcher repeated the story page by page and sometimes stopped in a certain page if there was difficult word that the students did not understand. Then the researcher explained the words in order to help them familiar with the meaning of the words. In helping the students comprehending the story, the researcher gave some questions related with the Big Book to the students. The students answered the questions enthusiastically. It was in line with the statement by Fahmi et al., (2014) who state that one of the benefits of Big Book was increased students' participation in reading class activity.

The fourth activity was after reading activity. In this activity, the researcher helped the students to connect one concept with another concept by relating their own experiences to the meaning of the story as well as their own language to the text. Then, the researcher and the students read the story together. In this activity the students enjoyed reading together with the researcher. It was line with Rahim \& Harun (2010) who stated that the use of the big book seemed to be of an advantage as it creates fun and meaningful learning of English in the classroom, as well as making reading activity an enjoyable one. Furthermore, the researcher chose the students randomly to read the story.

The last activity was close activity. In this activity, the researcher checked students reading comprehension by doing matching game for the first book, arranging game for the second book, guessing game for the third book, and simmon says game for the last book. The students were enthusiastic, active, and happy during this activity. It showed that Big Book as media in teaching reading comprehension on young learners had better effect than the conventional media.

As the subject of this study, young learners have their own characteristics which need to be understood by those who wish to be successful in teaching English for young learners. The teacher should have well preparation before teaching young learners in order to make them enthusiast and focus in learning process and make the learning process fun and enjoyable. Hall \& O'connor (2006) stated that big book is a larger format book with big illustrations and big texts. Big Book is large print and colorful illustrations that can make students become more 
focus and understand about the content of the story. It was proven in this research in which Big Book as media helped the students to comprehend the meaning of the text given. It because reading a Big Book is one of activitiess that can encourage the students to read and comprehend the story (Rahim \& Harun, 2010).

The result of this study supported the findings of some empirical studies. Tatminingsih (2013) who conducted research entitled Big Book, a Teaching Alternative for Improving Children's Reading Readiness in Kindergarten that had purpose to improve children's reading readiness in Kindergarten. The result was all children had a good improvement in their reading readiness by using Big Book. Moreover, this current study was also in line with Mahayanti, Artini, \& Jannah ( 2017) who conducted research entitled The Effect of Big Book as Media on Students' Reading Comprehension at Fifth Grade of Elementary School in SD Laboratorium Undiksha Singaraja. The result of this research showed that there was a significant difference of reading comprehension achievement between students treated by using Big Book as media and those treated by using conventional media.

The result of the present study was in line to the researchers presented in the empirical review which found that Big Book as media had significant effect on students' reading comprehension. This study finds out that there is significant effect of Big Book as media on students' reading comprehension at second grade of elementary school in south Bali.

\section{CONCLUSION}

Based on the findings that have been presented on the previous chapter, it indicated that there was a significant different in reading comprehension achievement of students taught by using Big Books as teaching media and students taught by conventional media. The statistical analysis showed that the mean score of students' reading comprehension in experimental group was higher than the mean score of the students in control group. The mean score of the experimental group was 81.59 while the mean score of the control group was 73.64. It showed that reading comprehension of students in experimental group was better than students in control group. Moreover, based on the result of independent sample t-test, the inferential statistical analysis showed that the value of $\mathrm{t}$-observed $\left(\mathrm{t}_{\mathrm{obs}}\right)$ was higher than the value of $\mathrm{t}$ critical value $\left(t_{\mathrm{cv}}\right)$. It was found that the value of $t_{\mathrm{obs}}$ was 3.009 at $\mathrm{df}$ (degree of freedom) 42 that was 2.018. Therefore, the comparison between $t_{o b s}$ and $t_{c v}$ was $3.009>2.018$. Since the value of $t_{o b s}$ was higher than the $t_{\mathrm{cv}}$, then the null hypothesis was rejected $(\mathrm{H} 0)$ and alternative hypothesis $(\mathrm{H} \alpha)$ was accepted. It meant that there was significant effect of Big Books as teaching media on students' reading comprehension at second grade of elementary school in south Bali in academic year 2017/2018.

In relation to the result of the study, there are two suggestions which can be proposed by the researcher as follows.

a. Recommendation for English teacher in south Bali is to use Big Book as teaching media in teaching and learning process because Big Book is effective and appropriate in improving students' reading comprehension. Big Book can make the students active in answering question and participating in the classroom.

Recommendation for other researchers is to improve this kind of research that used Big Book on students' reading comprehension by conducting similar research on larger and different population by using many kinds of Big Book.

\section{REFERENCES}

Ananta, A. K. (2018). Developing Big Book as Media for Literacy Program for Second Grade Students in SD Laboratorium Undiksha Singaraja.

Fahmi, D. I., Suhartono, L., \& Arifin, Z. (2014). Improving students' reading comprehension using big book. Tanjungpura University.

Fisher, B. (1991). Joyful learning, A Whole Language Kindergarten. USA: Heinemann.

Hall, S. C., \& O'connor, B. (2006). Using Big Books: A Standards-Based Instructional Approach for Foreign Language Teacher Candidates in a PreK - 12 Program. Foregign 
Language Annals, 39(3), 487-506.

Harmer, J. (1998). How to teach English: an Introduction to the Practice of English Language Teaching. England.

Harmer, J. (2007). The Practice of English Language Teaching (Fourth Edi).

Huyen, N. T., \& Nga, K. T. (2003). Learning vocabulary through games: The effectiveness of learning vocabulary through games. Asian EFL Journal, 5(1), 1-15.

Juhana. (2014). Teaching English to Young Learners : Some Points to be Considered, 2(1), 4346.

Khruawan, P., \& Dennis, N. K. (2017). A study of English reading comprehension using content-based instruction approach. International Journal of Research-Granthaalayah, 5, $368-375$.

Mahayanti, N. W. S., Artini, L. P., \& Jannah, N. (2017). the Effect of Big Book As Media on Students' Reading Comprehension At Fifth Grade of Elementary School in $\mathrm{Sd}$ Laboratorium Undiksha Singaraja. International Journal of Language and Literature, 1(3), 2549-4287.

Mahayanti, N. W. S., \& Asrina, N. K. A. (2017). The Implementation of Big Book as Media to Teach Reading Comprehension for the Sixth Grade Students of Elementary School. 2ndnternational Conference on Innovative Research Across Disciplines, 134(Icirad), 184188.

Megawati, F., \& Wulandari, F. (2017). Promoting Big Book and Reading Corner to Support Gerakan Literasi Sekolah (GLS) In Primary School. Universitas Muhammadiyah Sidoarjo.

Panduan Gerakan Literasi Sekolah di Sekolah Dasar (2016).Panduan Gerakan Literasi Sekolah di Sekolah Dasar.Direktorat Jenderal Pendidikan Dasar dan Menengah Kementerian Pendidikan dan Kebudayaan.

Rahim, N. A., \& Harun, N. I. (2010). Students ' Perception Towards The Usage of the Big Book.

Seken, I. K., \& Artini, L. P. (2013). The Effect of Numbered Head Together and Question Answer Relationship Techniques on Students ' Reading Comprehension: A Comparative Study. E-Journal Program Pascasarjana Universitas Pendidikan Ganesha, 1.

Sinambela, E., Manik, S., \& Pangaribuan, R. E. (2015). Improving Students' Reading Comprehension Achievement by Using K-W-L Strategy. English Linguistics Research, 4(3), 13-29. https://doi.org/10.5430/elr.v4n3p13

Slattery, M., \& Willis, J. (2001). English for Primary Teachers : A handbook of activities \& classroom language. https://doi.org/10.1093/elt/56.4.429

Sukmahidayanti, T. (2015). The utilization of instructional media in teaching English to young learners ( A case study of an elementary school teacher in Bandung ). Journal of English and Education, 3(2), 90-100.

Tatminingsih, S. (2013). International Conference On Educational Research and Innovation. Big Book, A Teaching Alternative For Improving Children's Reading Readiness In Kindergarten. 